\title{
Ellipsis
}

2015

\section{Awko Taco}

Emily Poulliard

University of New Orleans

Follow this and additional works at: https://scholarworks.uno.edu/ellipsis

\section{Recommended Citation}

Poulliard, Emily (2015) "Awko Taco," Ellipsis: Vol. 42 , Article 3.

DOI: https://doi.org/10.46428/ejail.42.03

Available at: https://scholarworks.uno.edu/ellipsis/vol42/iss1/3

This Essay is brought to you for free and open access by the Department of English and Foreign Languages at ScholarWorks@UNO. It has been accepted for inclusion in Ellipsis by an authorized editor of ScholarWorks@UNO. For more information, please contact scholarworks@uno.edu. 


\title{
Awko Taco
}

\author{
Emily Poulliard
}

You look around the room hoping, praying, that there is somebody who can save you from the awkwardness you are feeling at this party. None of your friends have shown up yet, and the host is nowhere in sight. Walking around aimlessly is always an option, but where is the destination? Will you just walk along until you find something, anything to calm the insecurities of not being comfortable at this party? Suddenly, your eyes make contact with the most beautiful object beckoning you to walk towards it. The answer to your problems lies here, at the food table. Never have you been more grateful to see a plate of finger sandwiches. You eat the available snacks and desserts eagerly and feel far better than if you were just standing alone in the middle of the room. Why is it that the simple act of eating can make this situation so much easier?

Admittedly, we have all been in a situation in which food made us feel better, more comfortable. Whether it be at that awkward party or maybe a first date with that guy or gal you have been dying to go out with from your Chemistry class, food can make situations easier for us. Food makes us feel more comfortable because it can cause our company to feel more comfortable with us. The more we eat with someone, the more at ease they will feel. As written in the book People-Pleasing Through Eating: Sociotropy Predicts Greater Eating in Response to Perceived Social Pressure, "People who eat relatively heavily (in terms of quantity or types of food) are doing something that can make others feel comfortable" (Exline et al. 173). Reading this, I can relate that seeing other people at ease with chowing down makes me feel more comfortable around them. Causing others to feel better by eating in front of them can also be linked to the lack of intimidation initiated by the person eating. People who refrain from eating "pose a social comparative threat by outshining others in the self-control domain; thus, they may not seem as fun or likeable as those whose heavier eating prevents them from posing a similar threat" (Exline et al. 173). We are less awkward around and more likely to want to be in the company of a person who can happily eat around us. In turn, we make our partygoers, dates, and business associates feel better by stuffing our faces.

Yes, it is clear that we can make others feel more at ease this way, but how does the act of eating make $u s$ feel less awkward? No one is a stranger to the term "comfort food" as a respite from sad emotions every once in a while. Sometimes that chocolate bar just has the ability to make us feel happier. If a snack during our time of sadness eases our pain, why would food not have the same effect in a social situation? The Mayo Health Clinic writes in the article "Weight Loss: Gain Control of Emotional Eating" that "emotional eating is eating as a way to suppress or soothe negative emotions, such as stress, anger, fear, boredom, sadness and loneliness." Awkwardness can surely be added to their mix of negative emotions, as it is a close friend of stress, boredom, and even 
loneliness. The act of eating can turn our negative, awkward feelings into a more enjoyable experience. This is completely natural, as throughout most childhoods, food was often used as a reward: an ice-cream trip for getting good grades or going out to eat after winning a baseball game. "Because we equate food with happiness, we continue to turn to food for such comfort" (Gorman). Our emotional stability and the rewarding feeling associated with food make eating a source of happiness when we are not feeling comfortable.

Aside from the comfort we feel from food during awkward social outings, eating also gives us something to do. The distraction of food stops us from having to merely exist in the awkward air while twiddling our thumbs. As written in Eating Out: Social Differentiation, Consumption, and Pleasure, "eating out seems to be expanding as a form of entertainment" (Warde and Martins 1). This is essentially the purpose eating serves in social situations: entertainment for us when conversation is lacking. For example, being on a date and not having anything to say is remedied by taking a moment to enjoy the food. There is no need to make an escape when you have a perfectly good distraction residing on the plate in front of you.

As for the main reason we flock towards food when in social situations, Mel Dahl in Eating with Strangers? Now That's Food for Thought; Cooking, shares his theory that we eat together to celebrate the fact that we can. He writes that in the past humans could not eat plentifully, and now that we are able to, choosing to share meals with people is a meaningful experience. He describes the act of eating together as people "acknowledging a common humanity" (Dahl). This can be a reason why we choose to eat together for the celebratory meals, dates, and important meetings: because sharing a meal together is actually deeper than it seems.

With a "full tummy" comes a less socially awkward silent sufferer at a social event. Without the presence of food in social situations, we would have to find other means of comforting those who are with us as well as ourselves-forms of entertainment, and ways to share a connection with our company. Eating definitely assists us in the awkward situations we go through and will always have to go through in our lives. Next time you feel yourself gravitating towards the food table, do not fret, it is completely natural to rely on those finger sandwiches to ease your feelings of social awkwardness. 
Works Cited

Dahl, Mel. "Eating with Strangers? Now That's Food For Thought; Cooking." Ledger [Lakeland] 12 May 2005. NewsBank - Archives. Web. 10 Nov. 2014.

Exline, Julie J., et al. "People-Pleasing Through Eating: Sociotropy Predicts Greater Eating In Response To Perceived Social Pressure." Journal of Social \& Clinical Psychology 31.2 (2012): 169-193. Academic Search Complete. Web. 28 Oct. 2014.

Gorman, Kimberly. "Obesity Action Coalition » Comfort Foods - Why Do They Make Us Happy?" Obesity Action Coalition Comfort Foods Why Do They Make Us Happy Comments. N.p., n.d. Web. 2 Nov. 2014.

Warde, Alan, and Lydia Martens. Eating out Social Differentiation, Consumption, and Pleasure. Cambridge: Cambridge UP, 2000. Print.

"Weight Loss." Weight-loss: Gain Control of Emotional Eating. N.p., 1 Dec. 2012. Web. 4 Nov. 2014. 